Organometallics

Revised Version: 25 April 2021

\title{
Dissecting Transmetalation Reactions at the Molecular Level: Role of the Coordinated Anion in the Transmetalation Step of the Hiyama Cross-coupling Reaction
}

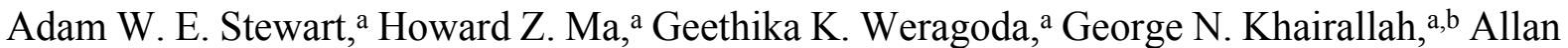
J. Canty, ${ }^{\mathrm{c}}$ and Richard A. J. O’Haira*

a School of Chemistry and Bio21 Molecular Science and Biotechnology Institute, University of Melbourne, 30 Flemington Rd, Parkville, Victoria 3010, Australia, Fax: (+) 6139347 8124; Email: rohair@unimelb.edu.au

${ }^{\mathrm{b}}$ Accurate Mass Scientific P/L, PO Box 92, Keilor, Victoria, Australia.

c School of Natural Sciences - Chemistry, University of Tasmania, Private Bag 75, Hobart, Tasmania 7001, Australia.

\section{Supporting Information:}




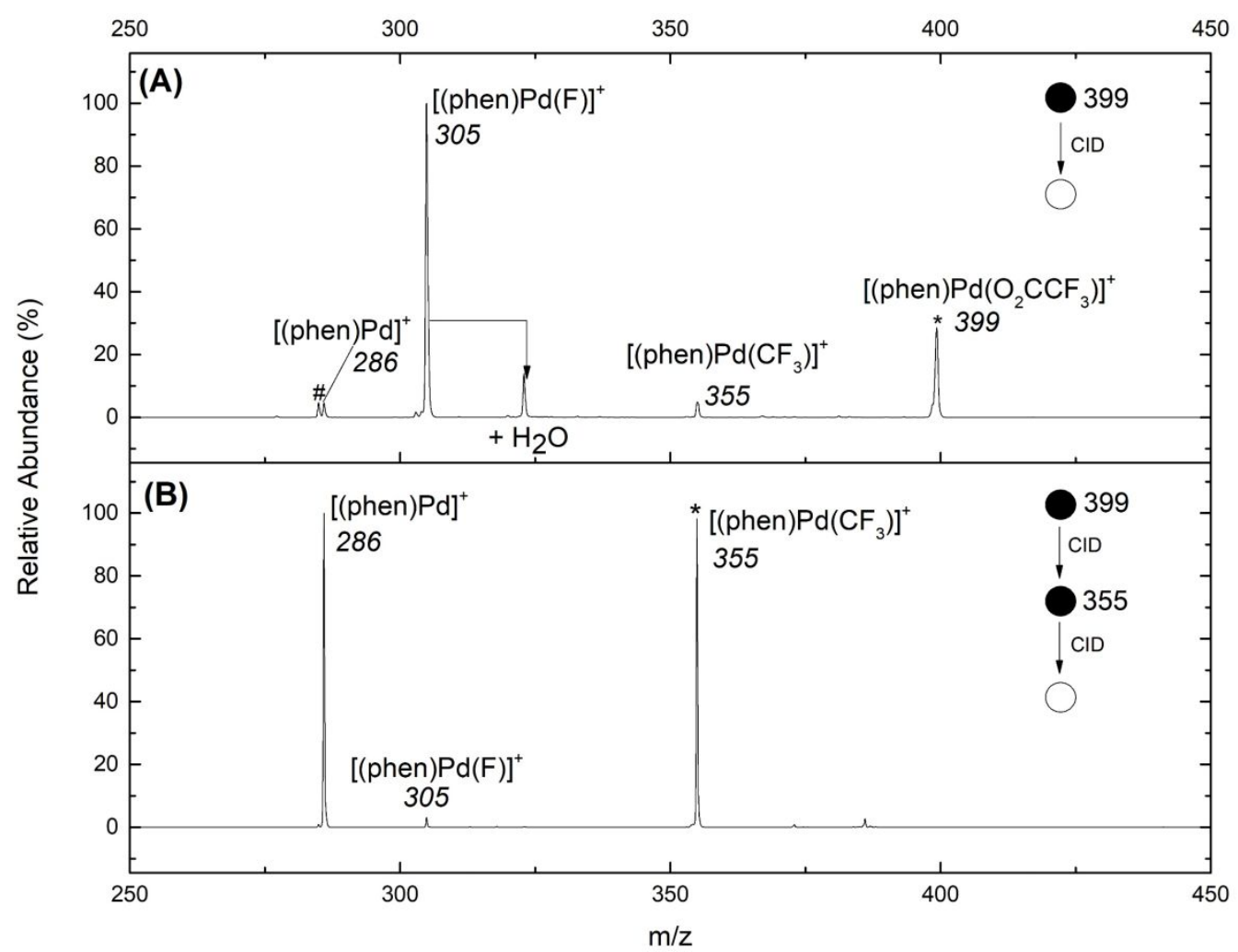

Figure S1. LTQ MS ${ }^{\mathrm{n}}$ spectra of unimolecular fragmentation reactions associated with the key steps for the formation of $[(\text { phen }) \mathrm{Pd}(\mathrm{F})]^{+}$from $\left[(\text {phen }) \mathrm{Pd}\left(\mathrm{O}_{2} \mathrm{CCF}_{3}\right)\right]^{+}$under CID conditions: (A) MS ${ }^{2}$ experiment involving competitive extrusion of $\mathrm{CO}_{2}$ (eq 2) and $\mathrm{CF}_{2} \mathrm{CO}_{2}$ (eq 1) from

$\left[(\text { phen }) \mathrm{Pd}\left(\mathrm{O}_{2} \mathrm{CCF}_{3}\right)\right]^{+}\left(\mathrm{m} / z\right.$ 399) at a normalized collision energy of 20 arbitrary units; (B) $\mathrm{MS}^{3}$ experiment involving extrusion of $\mathrm{CF}_{2}$ (eq 3$)$ from $\left[(\text { phen }) \mathrm{Pd}\left(\mathrm{CF}_{3}\right)\right]^{+}(\mathrm{m} / z$ 355) at a normalized collision energy of 20 arbitrary units. The mass-selected ions are denoted by asterisks. The peak at $\mathrm{m} / \mathrm{z} 285$ designated by a \# represents the species [(phen-H)Pd] .

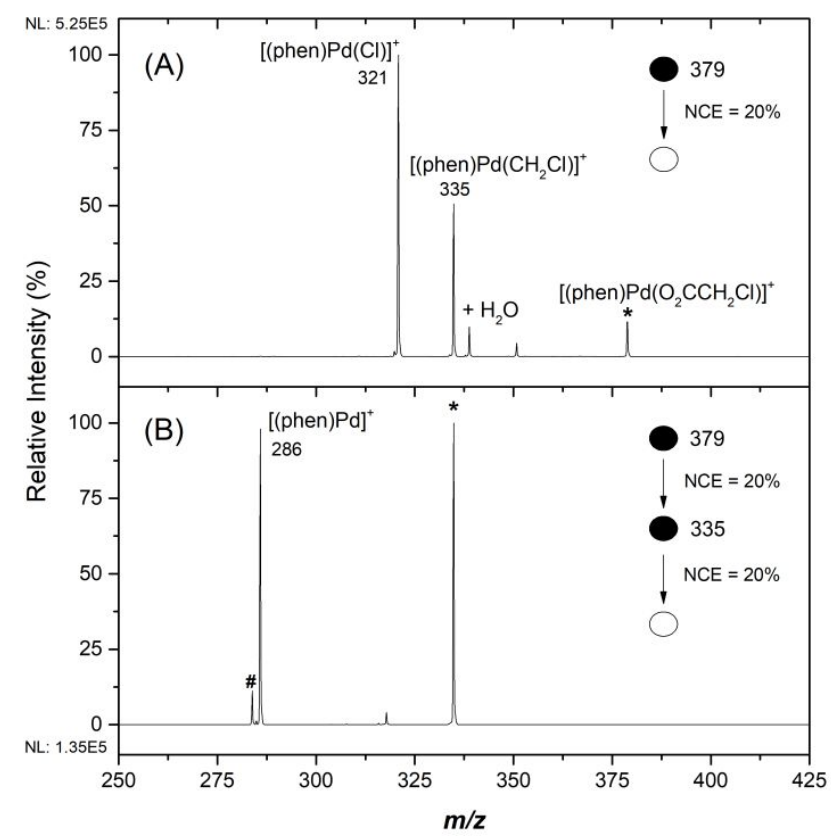

Figure S2. LTQ MS ${ }^{\mathrm{n}}$ spectra of unimolecular fragmentation reactions associated with the key steps for the formation of $[(\text { phen }) \mathrm{Pd}(\mathrm{Cl})]^{+}(\mathbf{1 0 b})$ from $\left[(\mathrm{phen}) \mathrm{Pd}\left(\mathrm{O}_{2} \mathrm{CCH}_{2} \mathrm{Cl}\right)\right]^{+}$under CID conditions: (A) $\mathrm{MS}^{2}$ experiment involving competitive extrusion of $\mathrm{CO}_{2}$ and $\mathrm{CH}_{2} \mathrm{CO}_{2}$ from $\left[(\text { phen }) \mathrm{Pd}\left(\mathrm{O}_{2} \mathrm{CCH}_{2} \mathrm{Cl}\right)\right]^{+}(\mathrm{m} / \mathrm{z}$ 
379) at a normalized collision energy of 20 arbitrary units; (B) $\mathrm{MS}^{3}$ experiment of [(phen) $\left.\mathrm{Pd}\left(\mathrm{CH}_{2} \mathrm{Cl}\right)\right]^{+}$ $(\mathrm{m} / \mathrm{z} 335)$ at a normalized collision energy of 20 arbitrary units. The mass-selected ions are denoted by asterisks (*). The peak at $\mathrm{m} / \mathrm{z} 285$ designated by a \# represents the species [(phen-H)Pd] ${ }^{+}$.

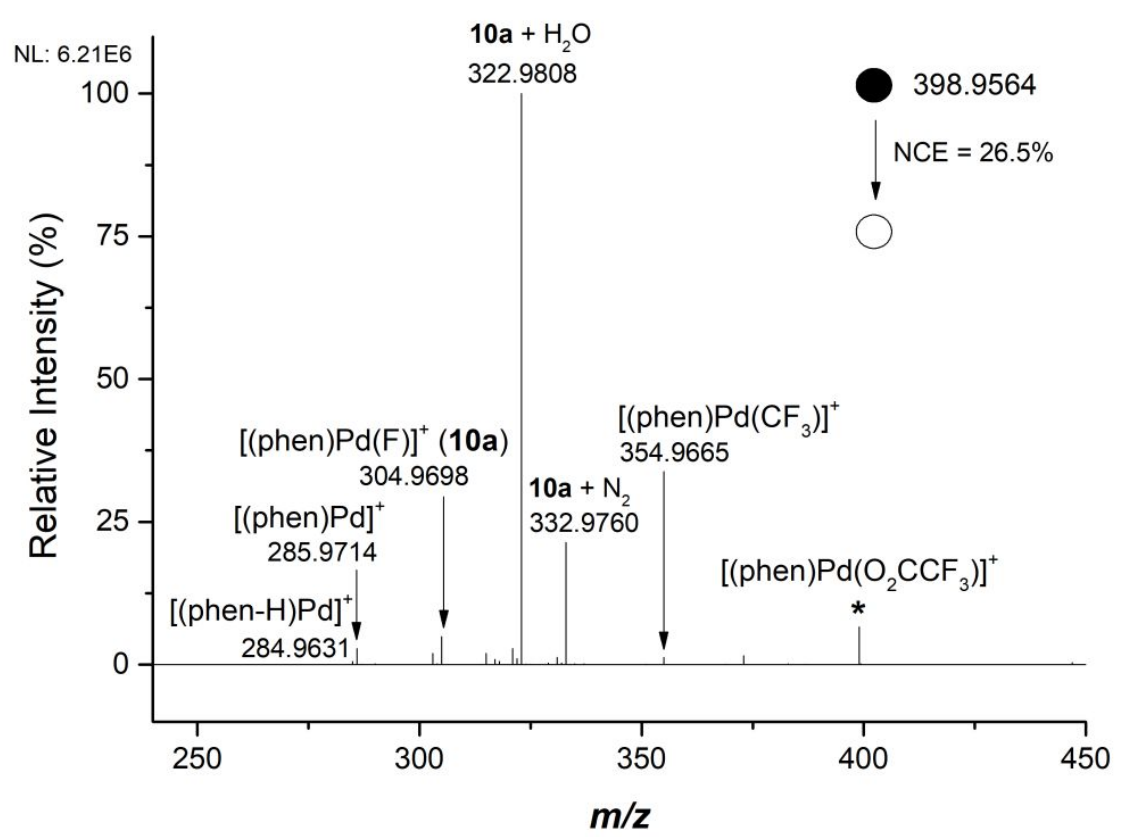

Figure S3. Single isotope $\mathrm{MS}^{2}$ low energy ion-trap CID experiment on $\left[(\text { phen }) \mathrm{Pd}\left(\mathrm{O}_{2} \mathrm{CCF}_{3}\right)\right]^{+}(\mathbf{1 0 a})(\mathrm{m} / \mathrm{z}$ $398.9564)$ as the mass-selected precursor ion, obtained using a $\mathrm{Q}$ value of 0.25 , an activation time of $10 \mathrm{~ms}$ and the normalized collision energy (NCE) $26.5 \%$. (*) represents mass-selected precursor ion.

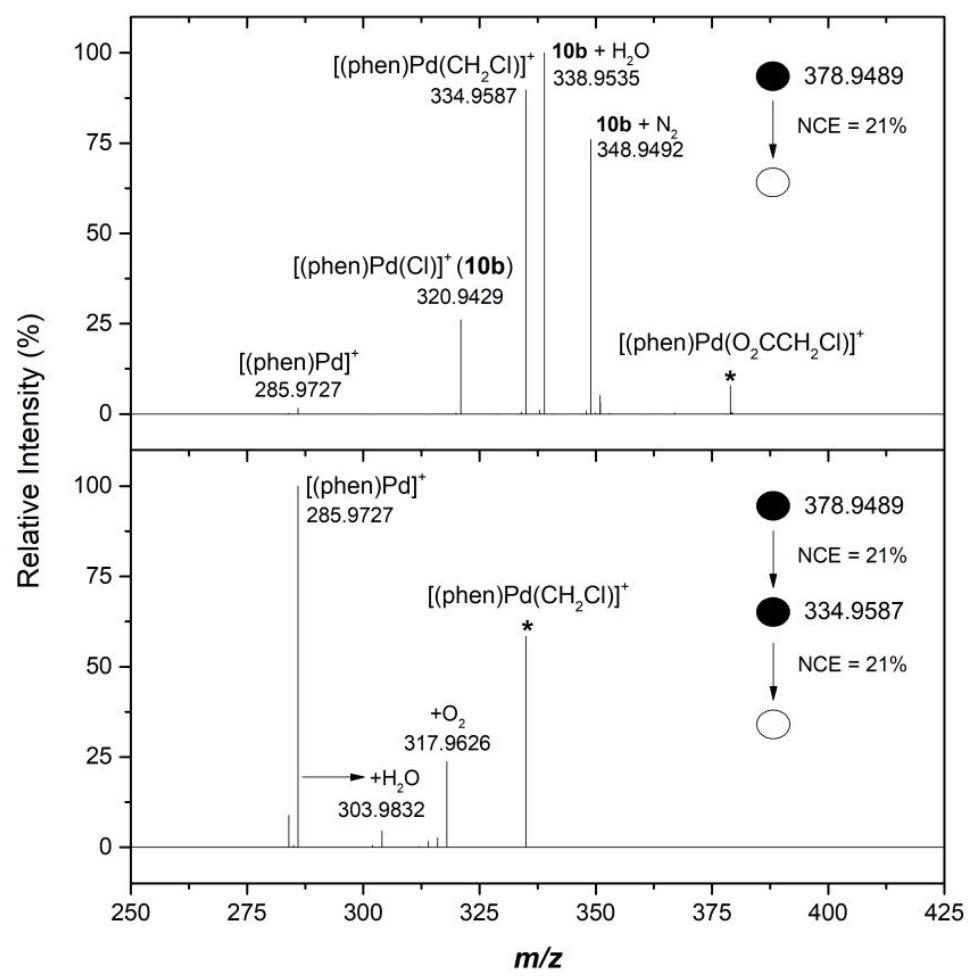

Figure S4. Single isotope $\mathrm{MS}^{\mathrm{n}}$ spectra of unimolecular fragmentation reactions associated with the key steps for the formation of $[(\text { phen }) \mathrm{Pd}(\mathrm{Cl})]^{+}(\mathbf{1 0 b})$ from $\left[(\text { phen }) \mathrm{Pd}\left(\mathrm{O}_{2} \mathrm{CCH}_{2} \mathrm{Cl}\right)\right]^{+}$under CID conditions: (A) $\mathrm{MS}^{2}$ experiment involving competitive extrusions of $\mathrm{CO}_{2}$ and $\mathrm{CH}_{2} \mathrm{CO}_{2}$ from $\left[(\text { phen }) \mathrm{Pd}\left(\mathrm{O}_{2} \mathrm{CCH}_{2} \mathrm{Cl}\right)\right]^{+}(\mathrm{m} / \mathrm{z} 378.9489)$ at a normalized collision energy of 21 arbitrary units; (B) $\mathrm{MS}^{3}$ 
experiment of $\left[(\text { phen }) \mathrm{Pd}\left(\mathrm{CH}_{2} \mathrm{Cl}\right)\right]^{+}(\mathrm{m} / z$ 334.9587) at a normalized collision energy of $21 \%$ arbitrary units. The mass-selected ions are denoted by asterisks $(*)$.

Table S1: HRMS experiments (Orbitrap Elite ETD linear ion trap mass spectrometer) confirming assignments of key ion formulae for the formation of $\left[(\text { phen }) \mathrm{Pd}\left(\mathrm{O}_{2} \mathrm{CCF}_{3}\right)\right]^{+}$(Fig. S8), its subsequent $\mathrm{MS}^{\mathrm{n}}$-CID experiment for the formation of $\left[(\text { phen) } \mathrm{Pd}(\mathrm{F})]^{+}\right.$(Fig. S3), and formation of $\mathrm{CF}_{3} \mathrm{CO}_{2}^{-}$(Fig. S9).

\begin{tabular}{|l|l|l|l|l|}
\hline Ion & Molecular Formula & $\begin{array}{l}\text { Exact mass - } \\
\text { calculated (m/z) }\end{array}$ & $\begin{array}{l}\text { Exact mass - } \\
\text { experimental (m/z) }\end{array}$ & $\begin{array}{l}\text { Mass error } \\
(\mathbf{p p m})\end{array}$ \\
\hline$\left[(\text { phen }) \mathrm{Pd}\left(\mathrm{O}_{2} \mathrm{CCF}_{3}\right)\right]^{+}$ & $\mathrm{N} 2 \mathrm{H} 8 \mathrm{C} 14 \mathrm{Pd} 1 \mathrm{~F} 3 \mathrm{O} 2$ & 398.9573 & 398.9573 & 0 \\
\hline $\mathrm{CF}_{3} \mathrm{CO}_{2}^{-}$ & $\mathrm{O} 2 \mathrm{C} 2 \mathrm{~F} 3$ & 112.9845 & 112.9847 & 1.8 \\
\hline$\left[2\left(\mathrm{CF}_{3} \mathrm{CO}_{2}\right)+\mathrm{H}\right]^{-}$ & $\mathrm{F} 6 \mathrm{C} 4 \mathrm{O} 4 \mathrm{H} 1$ & 226.9774 & 226.9770 & -1.8 \\
\hline$\left[(\text { phen }) \mathrm{Pd}\left(\mathrm{CF}_{3}\right)\right]^{+}$ & $\mathrm{N} 2 \mathrm{H} 8 \mathrm{C} 13 \mathrm{Pd} 1 \mathrm{~F} 3$ & 354.9674 & 354.9665 & -2.5 \\
\hline$[(\text { phen }) \mathrm{Pd}(\mathrm{F})]^{+}$ & $\mathrm{N} 2 \mathrm{H} 8 \mathrm{C} 12 \mathrm{Pd} 1 \mathrm{~F} 1$ & 304.9706 & 304.9698 & -2.6 \\
\hline$[(\text { phen }) \mathrm{Pd}]^{+}$ & $\mathrm{N} 2 \mathrm{H} 8 \mathrm{C} 12 \mathrm{Pd} 1$ & 285.9722 & 285.9714 & -2.8 \\
\hline$[(\text { phen- } \mathrm{H}) \mathrm{Pd}]^{+}$ & $\mathrm{N} 2 \mathrm{H} 7 \mathrm{C} 12 \mathrm{Pd} 1$ & 284.9643 & 284.9631 & -4.2 \\
\hline
\end{tabular}

Table S2: HRMS experiments (Orbitrap Elite ETD linear ion trap mass spectrometer) confirming assignments of ion formulae for the formation of $\left[(\text { phen }) \mathrm{Pd}\left(\mathrm{O}_{2} \mathrm{CCH}_{2} \mathrm{Cl}\right)\right]^{+}(\mathrm{Fig}$. S10), its subsequent $\mathrm{MS}^{\mathrm{n}}$-CID experiment for the formation of $[(\mathrm{phen}) \mathrm{Pd}(\mathrm{Cl})]^{+}$(Fig. S4), formation of $\mathrm{CF}_{3} \mathrm{CO}_{2}{ }^{-}$(Fig. S11), and formation of $[(\text { phen }) \mathrm{Pd}(\mathrm{Cl})]^{+}$from $\left[(\mathrm{phen}) \mathrm{Pd}(\mathrm{Cl})\left(\mathrm{CH}_{3} \mathrm{CN}\right)\right]^{+}$(Fig. S13).

\begin{tabular}{|l|l|l|l|l|}
\hline Ion & Molecular Formula & $\begin{array}{l}\text { Exact mass - } \\
\text { calculated } \\
(\mathbf{m} / \mathbf{z})\end{array}$ & $\begin{array}{l}\text { Exact mass } \\
\text { experimental } \\
(\mathbf{m} / \mathbf{z})\end{array}$ & $\begin{array}{l}\text { Mass error } \\
\text { (ppm) }\end{array}$ \\
\hline$\left[(\text { phen}) \mathrm{Pd}\left(\mathrm{O}_{2} \mathrm{CCH}_{2} \mathrm{Cl}\right)\right]^{+}$ & $\mathrm{N} 2 \mathrm{H} 10 \mathrm{C} 14 \mathrm{Pd} 1 \mathrm{Cl1} \mathrm{O} 2$ & 378.9458 & 378.9459 & 0.3 \\
\hline $\mathrm{CH}_{2} \mathrm{ClCO}_{2}^{-}$ & $\mathrm{O} 2 \mathrm{C} 2 \mathrm{H} 2 \mathrm{Cl1}$ & 92.9738 & 92.9743 & 5.4 \\
\hline$\left[(\text { phen }) \mathrm{Pd}\left(\mathrm{CH}_{2} \mathrm{Cl}\right)\right]^{+}$ & $\mathrm{N} 2 \mathrm{H} 10 \mathrm{C} 13 \mathrm{Pd} 1 \mathrm{Cl1}$ & 334.9564 & 334.9590 & 7.8 \\
\hline$[(\text { phen }) \mathrm{Pd}(\mathrm{Cl})]^{+}$ & $\mathrm{N} 2 \mathrm{H} 8 \mathrm{C} 12 \mathrm{Pd} 1 \mathrm{Cl1}$ & 320.9407 & 320.9429 & 6.9 \\
\hline$[(\text { phen }) \mathrm{Pd}]^{+}$ & $\mathrm{N} 2 \mathrm{H} 8 \mathrm{C} 12 \mathrm{Pd} 1$ & 285.9722 & 285.9727 & 1.8 \\
\hline$\left[(\mathrm{phen}) \mathrm{Pd}(\mathrm{Cl})\left(\mathrm{CH}{ }_{3} \mathrm{CN}\right)\right]^{+}$ & $\mathrm{N} 3 \mathrm{H} 11 \mathrm{C} 14 \mathrm{Pd} 1 \mathrm{Cl1}$ & 361.9671 & 361.9670 & -0.3 \\
\hline
\end{tabular}


$\Delta \mathrm{E}(\mathrm{kJ} / \mathrm{mol})$

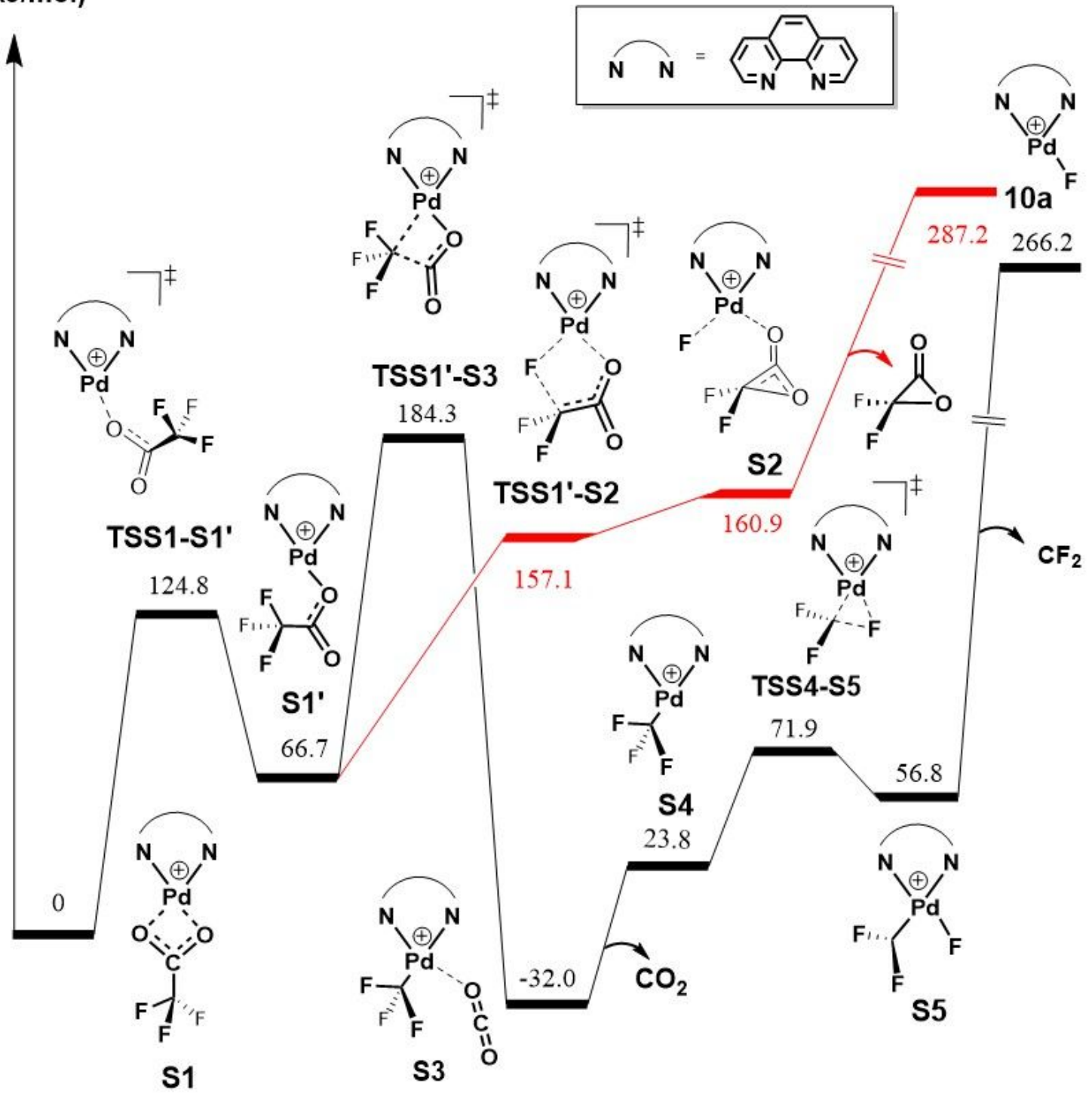

Decarboxylation

Carbene extrusion

Lactone extrusion

Figure S5. DFT calculated energy surface for the fragmentation reactions of $\left[(\mathrm{phen}) \mathrm{Pd}\left(\mathrm{O}_{2} \mathrm{CCF}_{3}\right)\right]^{+}$ resulting in the formation of $[(\mathrm{phen}) \mathrm{Pd}(\mathrm{F})]^{+}$. The relative enthalpies $(0 \mathrm{~K})$ are given in $\mathrm{kJ} / \mathrm{mol}$ and are the B3LYP-D3BJ/BS2 single point energies corrected for the M06/BS1 zero-point vibrational energies.

\section{Discussion}

$[(\text { phen }) \mathrm{Pd}(\mathrm{F})]^{+}$was formed from the palladium ligated trifluoroacetate, $\left[(\text {phen }) \mathrm{Pd}\left(\mathrm{O}_{2} \mathrm{CCF}_{3}\right)\right]^{+}$, in the gas-phase under conditions of collision-induced dissociation (CID). This transformation involves C-F bond activation, a class of reaction of continued interest. ${ }^{\mathrm{S} 1}$ Based on the CID MS${ }^{2}$ and $\mathrm{MS}^{3}$ spectra (Figures S1A and S1B) and previous gas-phase studies on the formation of related group 11 organometalates, ${ }^{\mathrm{S} 2}$ there are two potential competing pathways. The first involves a concerted reaction in which the difluorolactone, $\left(\mathrm{CF}_{2} \mathrm{CO}_{2}\right)$, is lost via fluoride transfer to the palladium center (eq 1). The 
second involves a stepwise process proceeding via decarboxylation (eq 2) (S3 $^{\mathrm{S}}$ followed by extrusion of difluorocarbene (eq 3). ${ }^{\mathrm{S} 4} \mathrm{~A}$ comparison of Figures S1A and S1B reveals that CID of $\left[(\text { phen }) \mathrm{Pd}\left(\mathrm{O}_{2} \mathrm{CCF}_{3}\right)\right]^{+}(\mathrm{m} / \mathrm{z} 399)$ produced the desired palladium ligated fluoride, $[(\mathrm{phen}) \mathrm{Pd}(\mathrm{F})]^{+}(\mathrm{m} / \mathrm{z}$ $305)$ and its water adduct $\left[(\mathrm{phen}) \mathrm{Pd}(\mathrm{F})\left(\mathrm{OH}_{2}\right)\right]^{+}(\mathrm{m} / \mathrm{z} 323)$ formed via reaction of 10a with adventitious water. Similar water adducts of $[(\mathrm{phen}) \mathrm{Pd}(\mathrm{R})]^{+}$complexes have been reported previously. ${ }^{\mathrm{S} 5}$ $\left[(\mathrm{phen}) \mathrm{Pd}\left(\mathrm{CF}_{3}\right)\right]^{+}(\mathrm{m} / z \text { 355), [(phen)Pd }]^{+}(\mathrm{m} / \mathrm{z} 286)$ and [(phen-H)Pd $]^{+}(\mathrm{m} / z 285)$ were observed as minor product ions (Figure S1A). In contrast, $\left[(\text { phen }) \operatorname{Pd}\left(\mathrm{CF}_{3}\right)\right]^{+}(\mathrm{m} / z$ 355) mainly fragments via bond homolysis (eq 4, Figure S1B), a reaction previously observed in the fragmentation of $\left[(\text { phen }) \operatorname{Pd}\left(\mathrm{CH}_{3}\right)\right]^{+} .{ }^{\mathrm{S} 6}$ This suggests that the difluorolactone pathway (eq 1) is preferred over the sequential losses of $\mathrm{CO}_{2}$ and $\mathrm{CF}_{2}$ (eq $2 \rightarrow$ eq S3).

To gain insights into the mechanisms for the competing pathways for formation of $[(\mathrm{phen}) \mathrm{Pd}(\mathrm{F})]^{+}$, Density Functional Theory (DFT) calculations were carried out and the results of these studies are shown in Figure S5. Both pathways involve a change in coordination of the trifluoroacetate ligand from binding through both $\mathrm{O}$ atoms in a bidentate fashion in $\mathbf{S 1}$ to binding through only one $\mathrm{O}$ atom in S1'. This occurs via TSS1-S1', which has a lower barrier than either the subsequent lactone extrusion pathway via TSS1'-S2, or the initial decarboxylation step via TSS1'-S3. The latter results in the formation of the $\mathrm{CO}_{2}$ coordinated organometallic cation $\left[(\text { phen }) \mathrm{Pd}\left(\mathrm{CF}_{3}\right)(\mathrm{OCO})\right]^{+}, \mathbf{S 3}$, which loses $\mathrm{CO}_{2}$ to produce $\left[(\text { phen }) \operatorname{Pd}\left(\mathrm{CF}_{3}\right)\right]^{+}, \mathbf{S 4}$, which then undergoes a transfer of fluorine from carbon to palladium via TSS3-S5 to form the coordinated carbene $\left[(\mathrm{phen}) \mathrm{Pd}(\mathrm{F})\left(\mathrm{CF}_{2}\right)\right]^{+}, \mathbf{S 5}$, which undergoes barrierless $\mathrm{CF}_{2}$ carbene loss. Although the enthalpies for formation of the lactone $(+287.2 \mathrm{~kJ} / \mathrm{mol})$ versus formation of $\mathrm{CO}_{2}$ and $\mathrm{CF}_{2}(+266.2 \mathrm{~kJ} / \mathrm{mol})$ are similar, the barrier for lactone extrusion TSS1'-S2 $(+157.1 \mathrm{~kJ} / \mathrm{mol})$ is lower than for decarboxylation TSS1'-S3 $(+184.3 \mathrm{~kJ} / \mathrm{mol})$. Furthermore, following decarboxylation to form S3 via TSS1'-S3, ensuing CF $_{2}$ extrusion is quite energetically unfavourable $(+298.2 \mathrm{~kJ} / \mathrm{mol})$ and greater than: 1$)$ the reverse reaction to reform $\mathbf{S 1}{ }^{\prime}(+216.3 \mathrm{~kJ} / \mathrm{mol})$, the overall enthalpy required to form $\mathbf{S 6}$ via lactone extrusion $(+287.2 \mathrm{~kJ} / \mathrm{mol})$. This suggests that the majority of $[(\mathrm{phen}) \mathrm{Pd}(\mathrm{F})]^{+}$formed in Figure S1A occurs via the lactone pathway. This is consistent with the $\mathrm{MS}^{3}$ experiments, where formation of $[(\mathrm{phen}) \mathrm{Pd}(\mathrm{F})]^{+}$via fragmentation of $\left[(\mathrm{phen}) \mathrm{Pd}\left(\mathrm{CF}_{3}\right)\right]^{+}$is only a minor pathway (Figure S1B). 


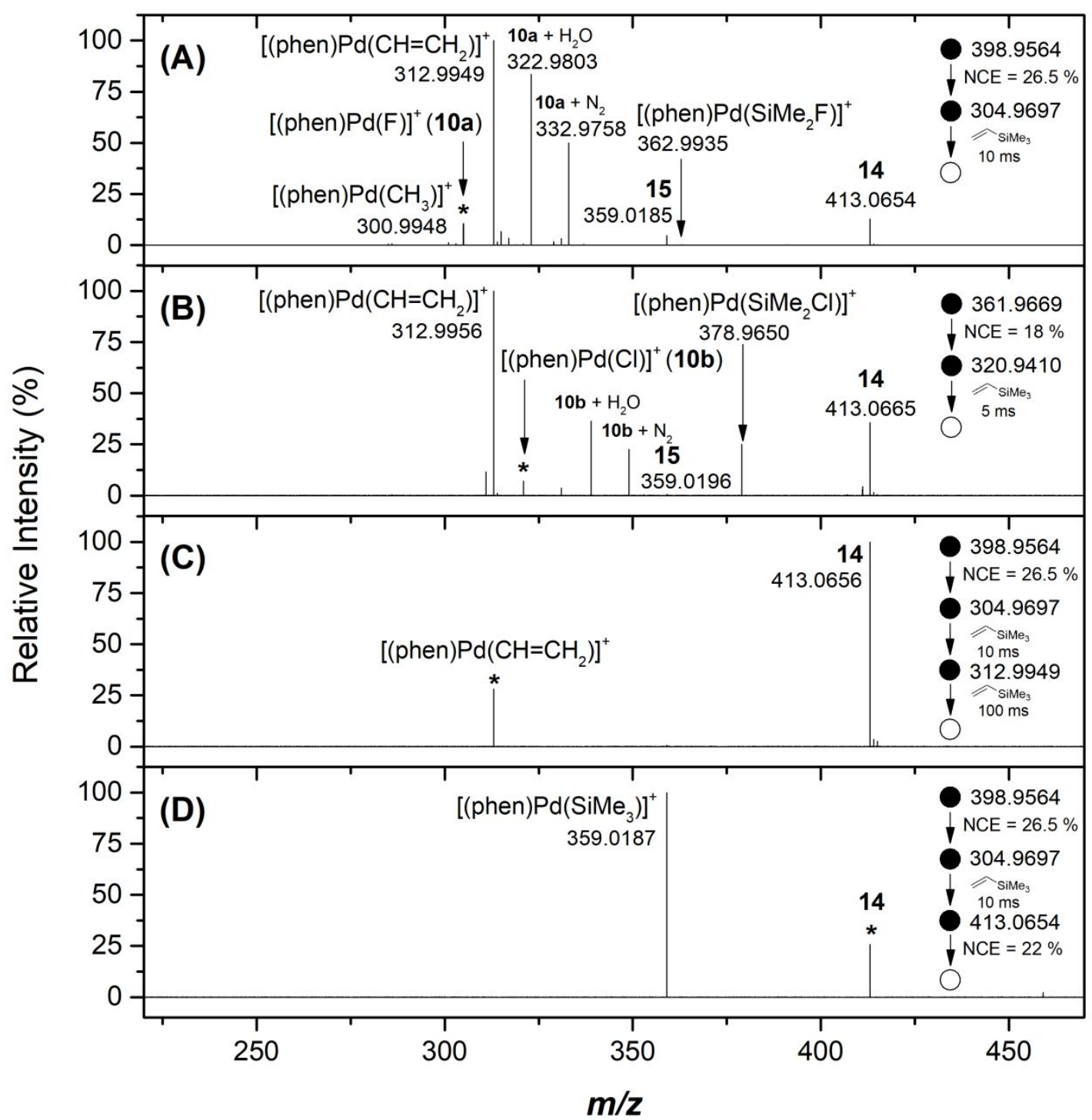

Figure S6: Single isotope $\mathrm{MS}^{\mathrm{n}}$ spectra showing the reactions of $[(\text { phen }) \operatorname{Pd}(\mathrm{F})]^{+}(\mathbf{1 0 a})$ and $[(\text { phen }) \mathrm{Pd}(\mathrm{Cl})]^{+}(\mathbf{1 0 b})$ with vinyltrimethylsilane: (A) $\mathrm{MS}^{3}$ IMR experiment showing reactions of $[(\text { phen }) \mathrm{Pd}(\mathrm{F})]^{+}$with vinyltrimethylsilane for $10 \mathrm{~ms}$ giving rise to primary and secondary products; (B) $\mathrm{MS}^{3}$ IMR experiment showing reactions of $[(\mathrm{phen}) \mathrm{Pd}(\mathrm{Cl})]^{+}$with vinyltrimethylsilane for $5 \mathrm{~ms}$ giving rise to primary and secondary products; (C) $\mathrm{MS}^{4}$ IMR experiment showing the reaction of $\left[(\text { phen }) \mathrm{Pd}\left(\mathrm{CH}=\mathrm{CH}_{2}\right)\right]^{+}$with vinlytrimethylsilane for $100 \mathrm{~ms}$; (D) CID-MS ${ }^{4}$ experiment showing loss of 1,3-butadiene from [(phen) $\left.\mathrm{Pd}\left(\mathrm{CH}=\mathrm{CH}_{2}\right)\left(\left(\mathrm{CH}=\mathrm{CH}_{2}\right) \mathrm{SiMe}_{3}\right)\right]^{+}(\mathbf{1 4})$ at a normalized collision energy of 20 arbitrary units. The mass-selected ions are denoted by asterisks $(*)$. 
Table S3: HRMS experiments (Orbitrap Elite ETD linear ion trap mass spectrometer) confirming assignments of product ion formulae for the ion-molecule reaction(s) of $[(\mathrm{phen}) \operatorname{Pd}(\mathrm{F})]^{+}(\mathbf{1 0 a})$ and $[(\mathrm{phen}) \mathrm{Pd}(\mathrm{Cl})]^{+}(\mathbf{1 0 b})$ with vinyltrimethylsilane (Fig. S6A-B).

\begin{tabular}{|c|c|c|c|c|}
\hline Ion & Molecular Formula & $\begin{array}{l}\text { Exact mass - } \\
\text { calculated } \\
(\mathbf{m} / \mathbf{z})\end{array}$ & $\begin{array}{l}\text { Exact mass - } \\
\text { experimental } \\
(\mathrm{m} / \mathrm{z})\end{array}$ & $\begin{array}{l}\text { Mass } \\
\text { error } \\
(p p m)\end{array}$ \\
\hline$[(\text { phen }) \operatorname{Pd}(\mathrm{F})]^{+}$ & N2 H8 C12 Pd1 F1 & 304.9706 & 304.9697 & -3.0 \\
\hline$\left[(\text { phen }) \mathrm{Pd}\left(\mathrm{CH}=\mathrm{CH}_{2}\right)\right]^{+}$ & N2 H11 C14 Pd1 & 312.9957 & 312.9949 & -2.6 \\
\hline$\left[(\text { phen }) \operatorname{Pd}\left(\mathrm{CH}_{3}\right)\right]^{+}$ & N2 H11 C13 Pd1 & 300.9957 & 300.9948 & -3.0 \\
\hline$\left[(\text { phen }) \operatorname{Pd}\left(\mathrm{SiMe}_{2} \mathrm{~F}\right)\right]^{+}$ & N2 H14 C14 Pd1 F1 Si1 & 362.9945 & 362.9935 & -2.8 \\
\hline$\left[(\text { phen }) \mathrm{Pd}\left(\mathrm{CH}=\mathrm{CH}_{2}\right)\left(\mathrm{CH}=\mathrm{CH}_{2}\left(\mathrm{SiMe}_{3}\right)\right)\right]^{+}$ & N2 H23 C19 Pd1 Si1 & 413.0667 & 413.0654 & -3.1 \\
\hline$\left[(\text { phen }) \operatorname{Pd}\left(\mathrm{SiMe}_{3}\right)\right]^{+}$ & N2 H17 C15 Pd1 Si1 & 359.0196 & 359.0185 & -3.1 \\
\hline$[(\text { phen }) \operatorname{Pd}(\mathrm{Cl})]^{+}$ & N2 H8 C12 Pd1 Cl1 & 320.9405 & 320.9410 & 1.6 \\
\hline$\left[(\text { phen }) \mathrm{Pd}\left(\mathrm{SiMe}_{2} \mathrm{Cl}\right)\right]^{+}$ & N2 H14 C14 Pd1 Cl1 Si1 & 378.9644 & 378.9650 & 1.6 \\
\hline
\end{tabular}

Table S4: Confirmation of adducts with background gases and moisture associated with $[(\mathrm{phen}) \mathrm{Pd}(\mathrm{F})]^{+}$ (10a) and $[(\text { phen }) \mathrm{Pd}(\mathrm{Cl})]^{+}(\mathbf{1 0 b})$.

\begin{tabular}{|c|c|c|c|c|}
\hline Ion & Molecular Formula & $\begin{array}{l}\text { Exact mass - } \\
\text { calculated } \\
(\mathbf{m} / \mathbf{z})\end{array}$ & $\begin{array}{l}\text { Exact mass - } \\
\text { experimental } \\
(\mathbf{m} / \mathbf{z})\end{array}$ & $\begin{array}{l}\text { Mass error } \\
(\mathrm{ppm})\end{array}$ \\
\hline$\left[(\text { phen }) \mathrm{Pd}(\mathrm{F})\left(\mathrm{OH}_{2}\right)\right]^{+}$ & N2 H10 C12 Pd1 F1 O1 & 322.9811 & 322.9808 & -0.9 \\
\hline$\left[(\text { phen }) \operatorname{Pd}(\mathrm{F})\left(\mathrm{N}_{2}\right)\right]^{+}$ & N4 H8 C12 Pd1 F1 & 332.9767 & 332.9760 & -2.1 \\
\hline$\left[(\text { phen }) \operatorname{Pd}\left(\mathrm{CF}_{3}\right)\left(\mathrm{OH}_{2}\right)\right]^{+}$ & N2 H10 C13 Pd1 F3 O1 & 372.9780 & 372.9770 & -2.7 \\
\hline$\left[\left(\text { phen-H)Pd}\left(\mathrm{OH}_{2}\right)\right]^{+}\right.$ & N2 H9 C12 Pd1 O1 & 302.9744 & 302.9741 & -1.0 \\
\hline$\left[(\text { phen-H }) \mathrm{Pd}\left(\mathrm{OH}_{2}\right)_{2}\right]^{+}$ & N2 H11 C12 Pd1 O2 & 320.9850 & 320.9847 & -0.9 \\
\hline$\left[(\text { phen }) \mathrm{Pd}(\mathrm{Cl})\left(\mathrm{OH}_{2}\right)\right]^{+}$ & N2 H10 C12 Pd1 Cl1 O1 & 338.9511 & 338.9517 & 1.8 \\
\hline$\left[(\text { phen }) \operatorname{Pd}(\mathrm{Cl})\left(\mathrm{N}_{2}\right)\right]^{+}$ & N4 H8 C12 Pd1 Cl1 & 348.9467 & 348.9473 & 1.7 \\
\hline
\end{tabular}




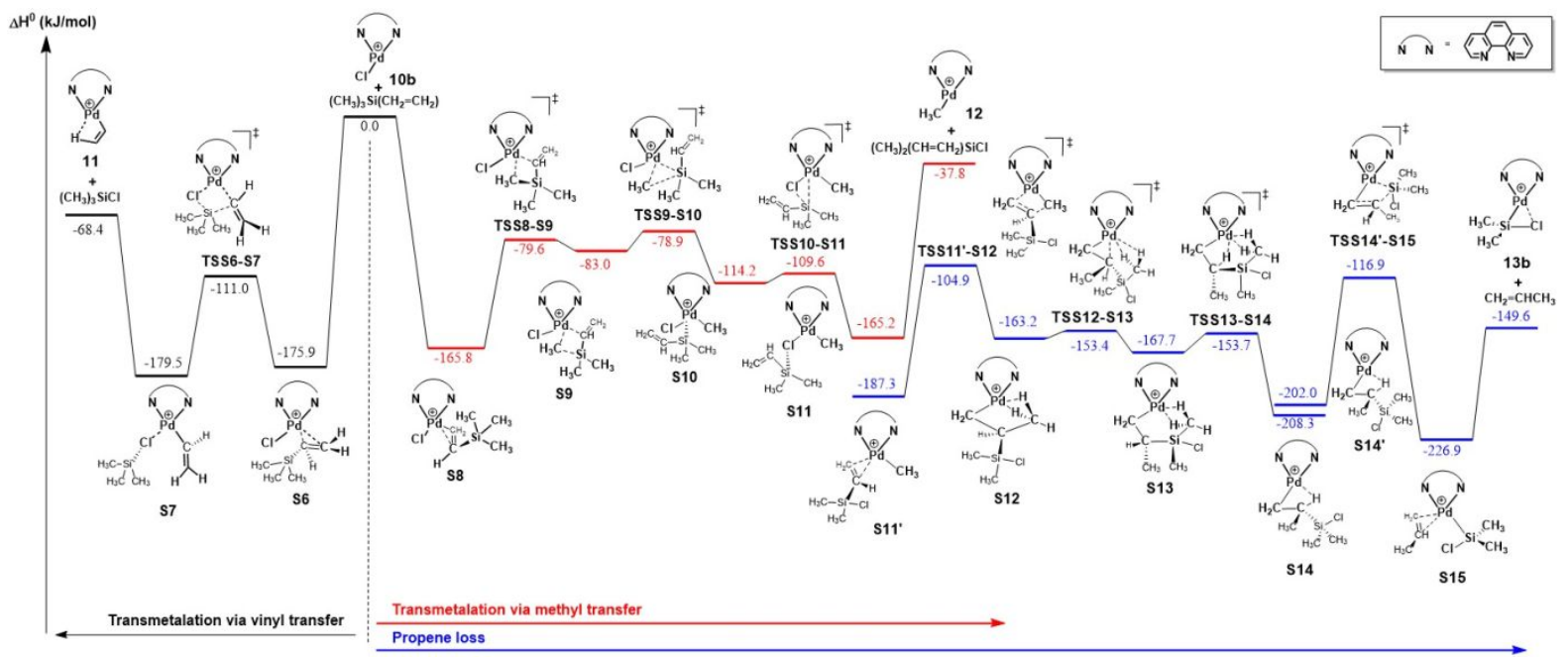

Figure S7: DFT calculated energy surface for the reaction of $[(\mathrm{phen}) \mathrm{Pd}(\mathrm{Cl})]^{+}$with vinyltrimethylsilane: primary reaction of eq 4 , minor product of eq 5 (red), and minor product of eq 6 (blue). The relative enthalpies $(0 \mathrm{~K})$ are given in $\mathrm{kJ} / \mathrm{mol}$ and are the B3LYP-D3BJ/BS2 single point energies corrected for the M06/BS1 zero-point vibrational energies.

Table S5: calculations of fluoride anion affinity (FAA) and chloride anion affinity (CAA) of $\mathrm{Me}_{3} \mathrm{Si}^{+}$based on known heats of formation $(\mathrm{kJ} / \mathrm{mol})$

$$
\begin{array}{cccc}
\mathrm{Me}_{3} \mathrm{SiX} & \rightarrow & \mathrm{Me}_{3} \mathrm{Si}^{+}+ & \mathrm{X}^{-} \\
\mathrm{X}=\mathrm{F} \quad \Delta \mathrm{H}_{\mathrm{f}}(-527) & \Delta \mathrm{H}_{\mathrm{f}}(630) & \Delta \mathrm{H}_{\mathrm{f}}(-249) & \mathrm{FAA}\left(\mathrm{Me}_{3} \mathrm{Si}^{+}\right)=\Delta \mathrm{H}_{\text {reaction }}=908 \\
\mathrm{X}=\mathrm{Cl} \Delta \mathrm{H}_{\mathrm{f}}(-354) & \Delta \mathrm{H}_{\mathrm{f}}(630) & \Delta \mathrm{H}_{\mathrm{f}}(-227) & \mathrm{CAA}\left(\mathrm{Me}_{3} \mathrm{Si}^{+}\right)=\Delta \mathrm{H}_{\text {reaction }}=757
\end{array}
$$

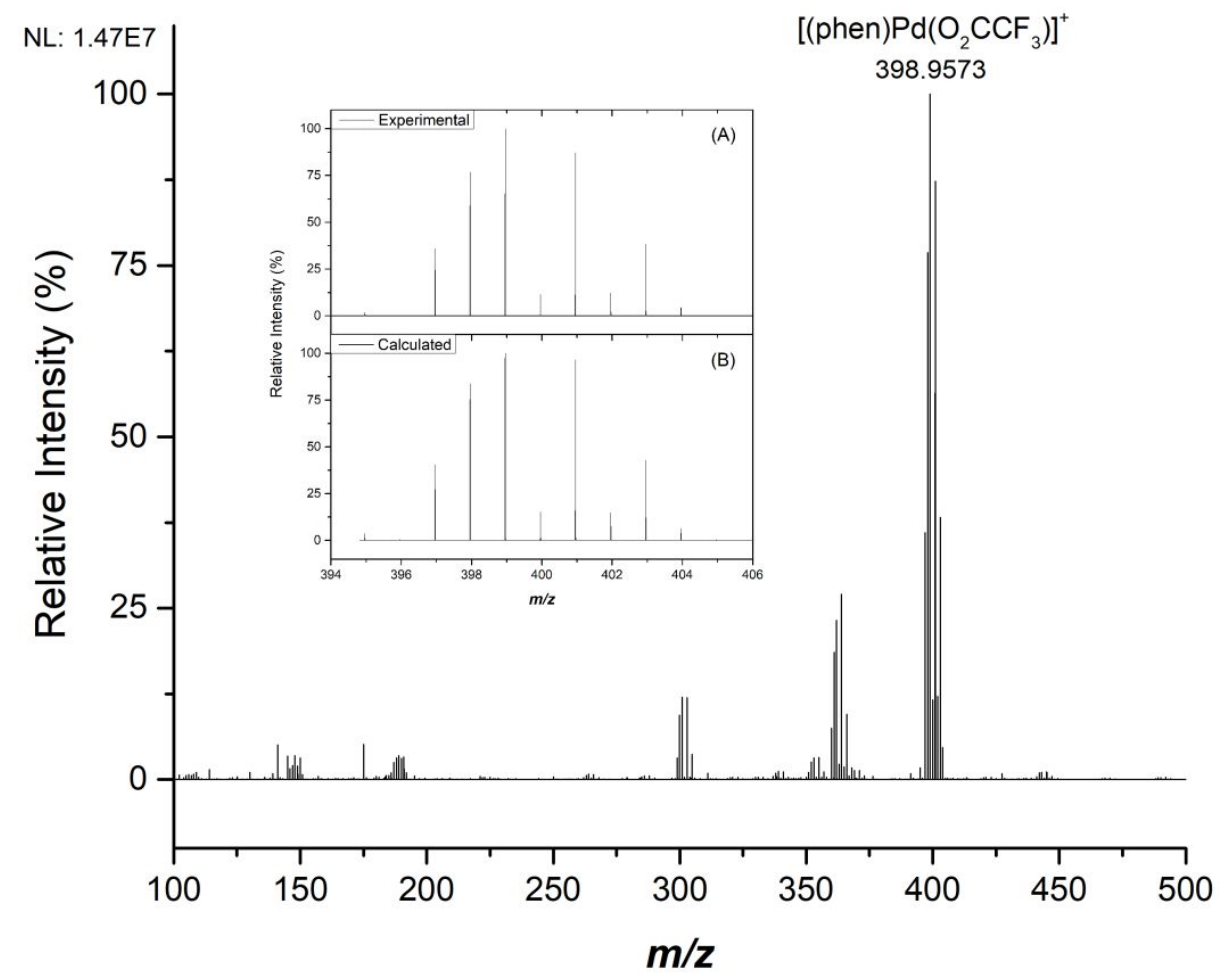


Figure S8: Orbitrap Elite ETD linear ion trap positive mode high resolution ESI-MS mass spectrum of a $1 \mu \mathrm{M}$ acetonitrile solution of the preparation of $\left[(\mathrm{phen}) \mathrm{Pd}\left(\mathrm{O}_{2} \mathrm{CCF}_{3}\right)\right]^{+}(\mathrm{m} / \mathrm{z} 398.9573(\mathrm{exp}) / \mathrm{m} / \mathrm{z}$ 398.9573 (calc)) from a 1:1 molar ratio of $\left[(\right.$ phen $\left.) \mathrm{Pd}\left(\mathrm{O}_{2} \mathrm{CCH}_{3}\right)_{2}\right]$ and 10 eq. of TFA. Inset shows the isotope pattern: experimental (top) vs. calculated (bottom).

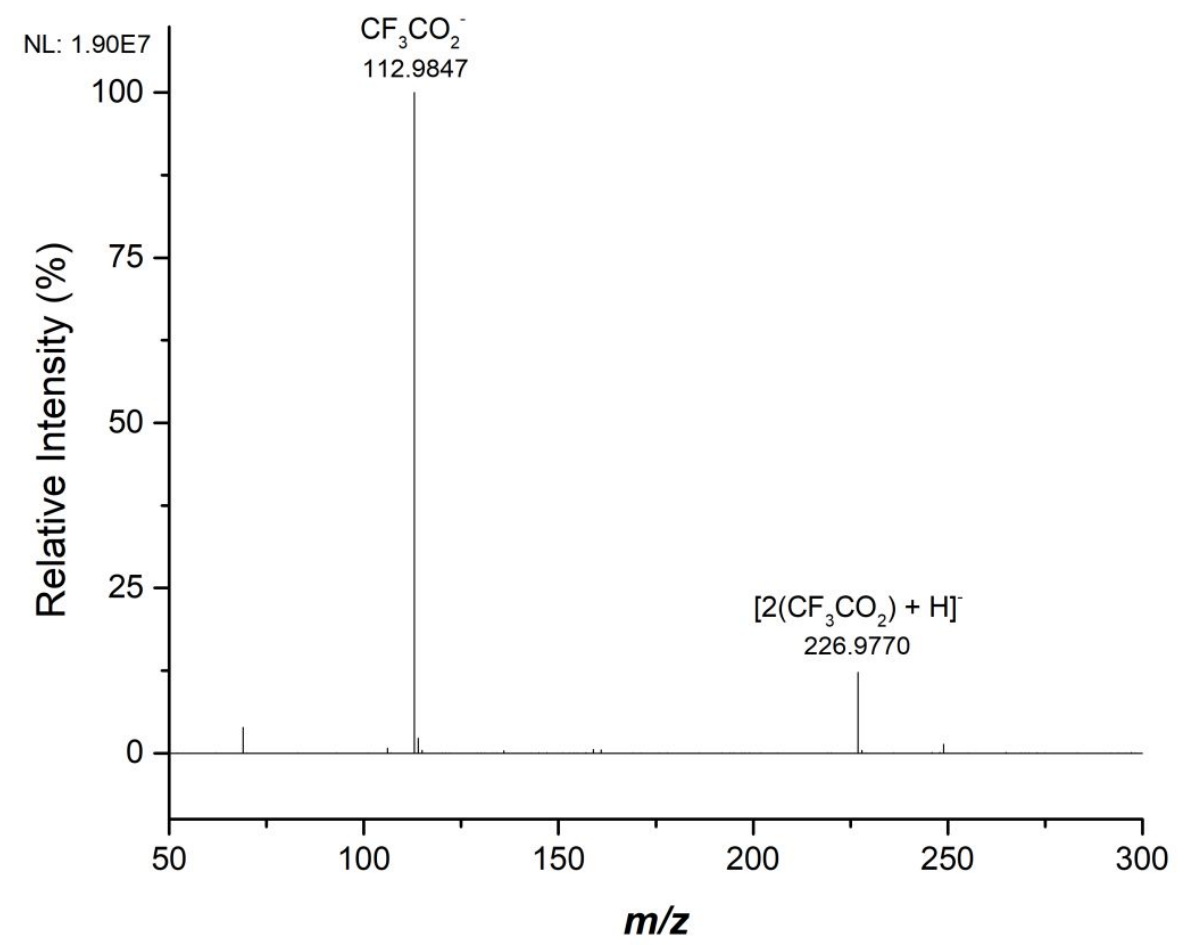

Figure S9: Orbitrap Elite ETD linear ion trap negative mode high resolution ESI-MS mass spectrum of a $1 \mu \mathrm{M}$ acetonitrile solution of 1:1 molar ratio of $\left[(\right.$ phen $\left.) \mathrm{Pd}\left(\mathrm{O}_{2} \mathrm{CCH}_{3}\right)_{2}\right]$ and 10 eq. of TFA.

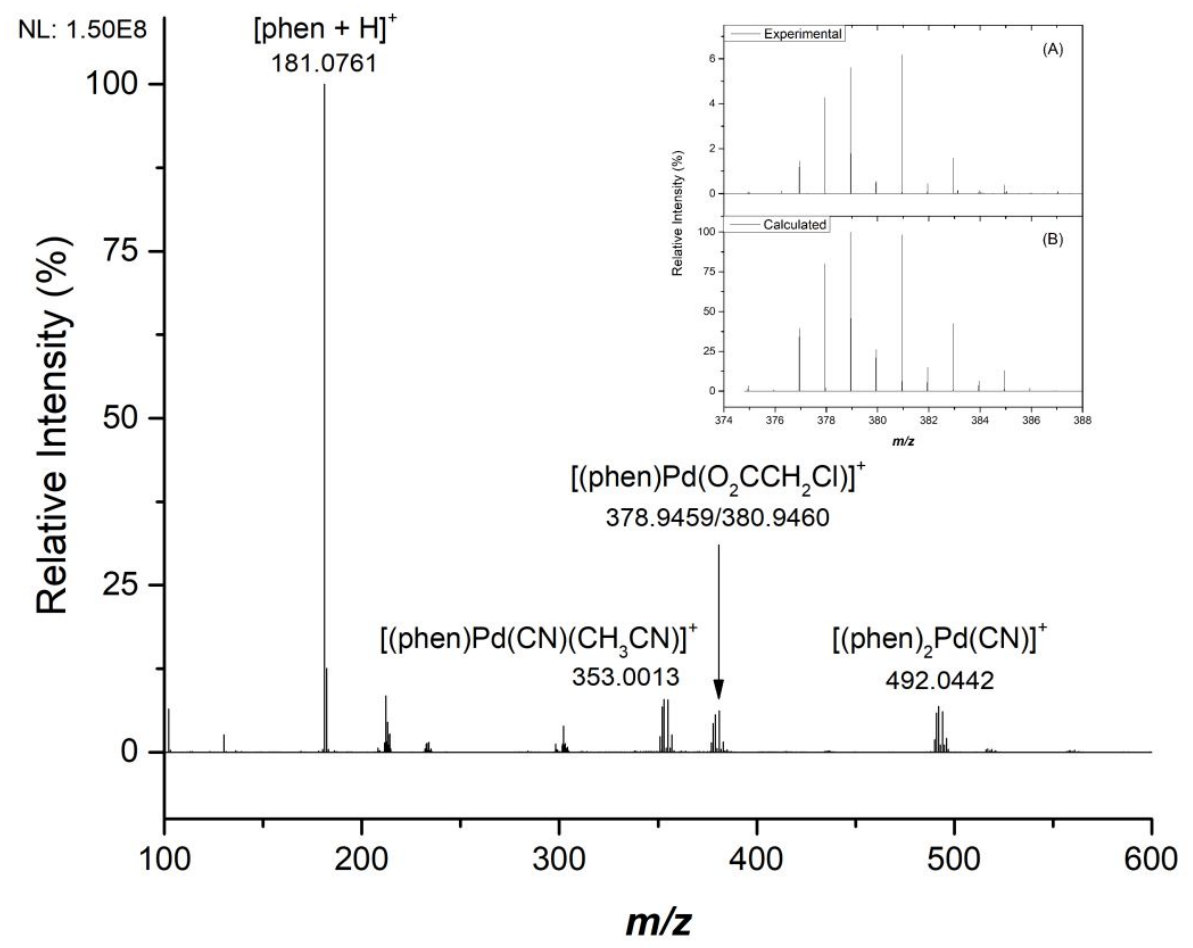


Figure S10: Orbitrap Elite ETD linear ion trap positive mode high resolution ESI-MS mass spectrum of a $1 \mu \mathrm{M}$ acetonitrile solution of the preparation of $\left[(\mathrm{phen}) \mathrm{Pd}\left(\mathrm{O}_{2} \mathrm{CCH}_{2} \mathrm{Cl}\right)\right]^{+}(\mathrm{m} / z 398.9459(\mathrm{exp}) / \mathrm{m} / z$ 378.9458 (calc)) from a 1:1 molar ratio of $\left[(\right.$ phen $\left.) \mathrm{Pd}\left(\mathrm{O}_{2} \mathrm{CCH}_{3}\right)_{2}\right]$ and 10 eq. of $\mathrm{ClCH}_{2} \mathrm{CO}_{2} \mathrm{H}$. Inset shows the isotope pattern: experimental (top) vs. calculated (bottom).

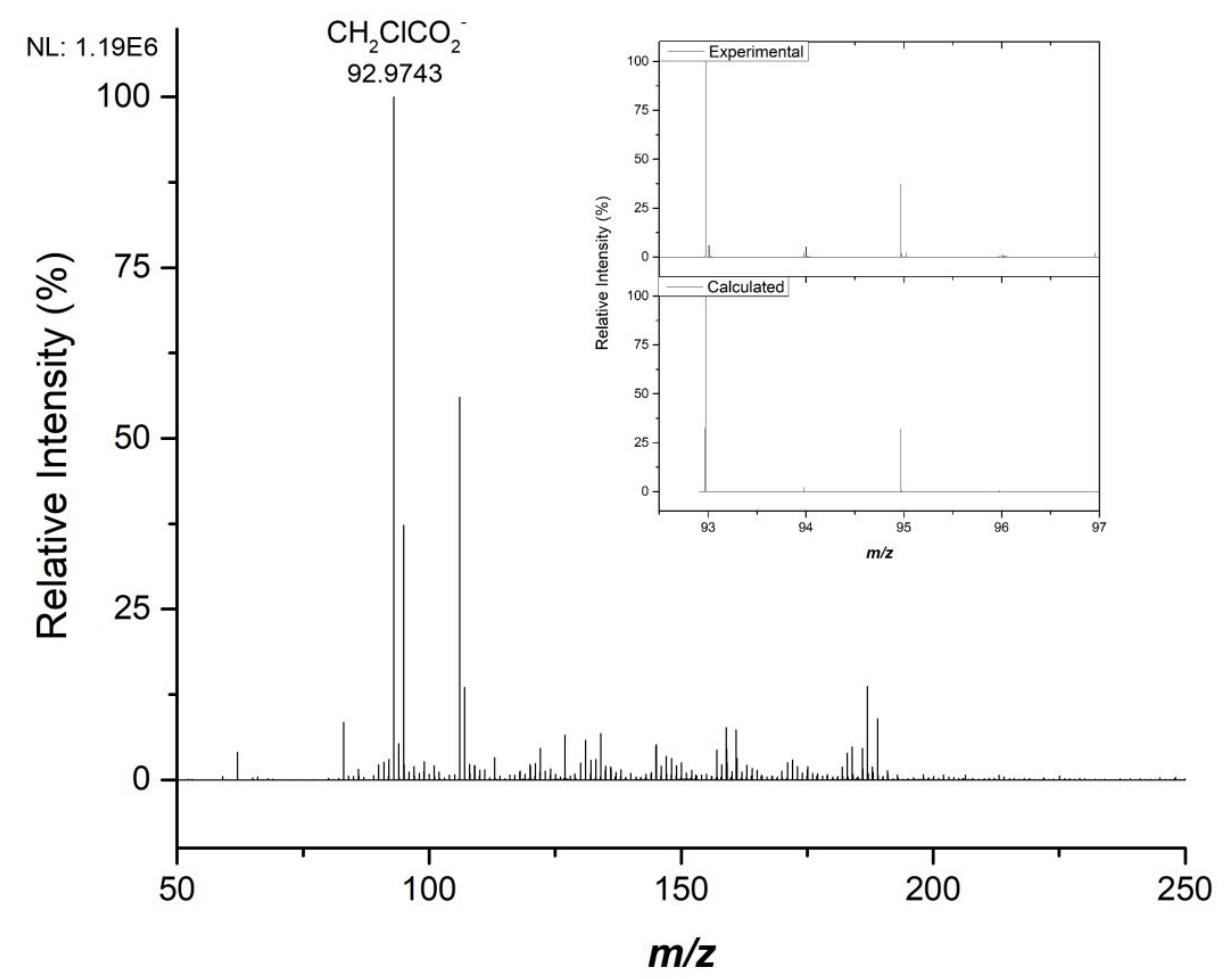

Figure S11: Orbitrap Elite ETD linear ion trap negative mode high resolution ESI-MS mass spectrum of a $1 \mu \mathrm{M}$ acetonitrile solution of 1:1 molar ratio of $\left[(\right.$ phen $\left.) \mathrm{Pd}\left(\mathrm{O}_{2} \mathrm{CCH}_{3}\right)_{2}\right]$ and 10 eq. of $\mathrm{ClCH}_{2} \mathrm{CO}_{2} \mathrm{H}$.

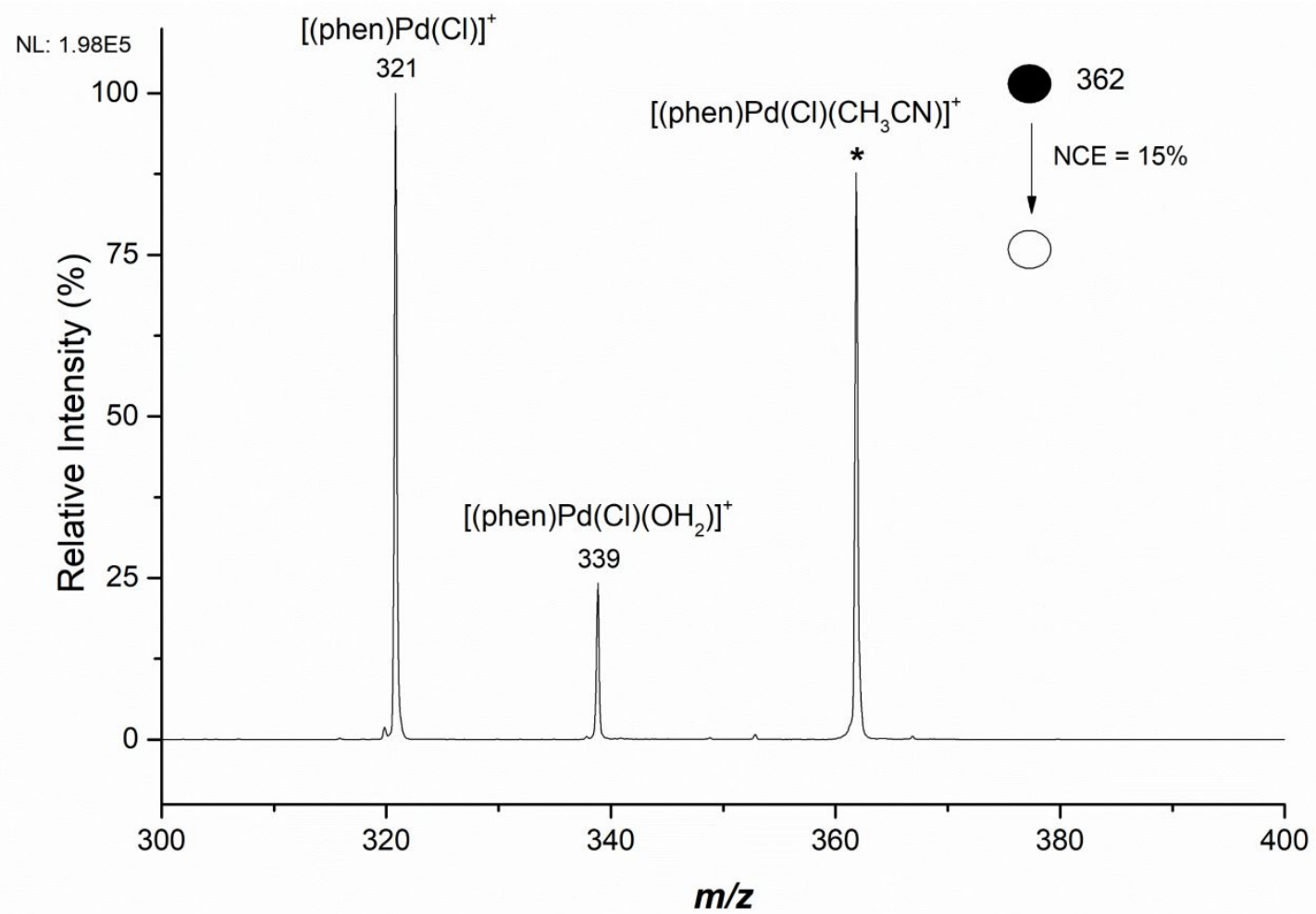


Figure S12. LTQ MS ${ }^{\mathrm{n}}$ spectra of unimolecular fragmentation reactions associated with the key steps for the formation of $[(\text { phen }) \mathrm{Pd}(\mathrm{Cl})]^{+}(\mathbf{1 0 b})$ from $\left[(\mathrm{phen}) \mathrm{Pd}(\mathrm{Cl})\left(\mathrm{CH}_{3} \mathrm{CN}\right)\right]^{+}$under CID conditions. MS ${ }^{2}$ experiment involving loss of $\mathrm{CH}_{3} \mathrm{CN}$ from $\left[(\text { phen }) \mathrm{Pd}(\mathrm{Cl})\left(\mathrm{CH}_{3} \mathrm{CN}\right)\right]^{+}(\mathrm{m} / z$ 362) at a normalized collision energy of 15 arbitrary units. The mass-selected ion is denoted by an asterisk $(*)$.

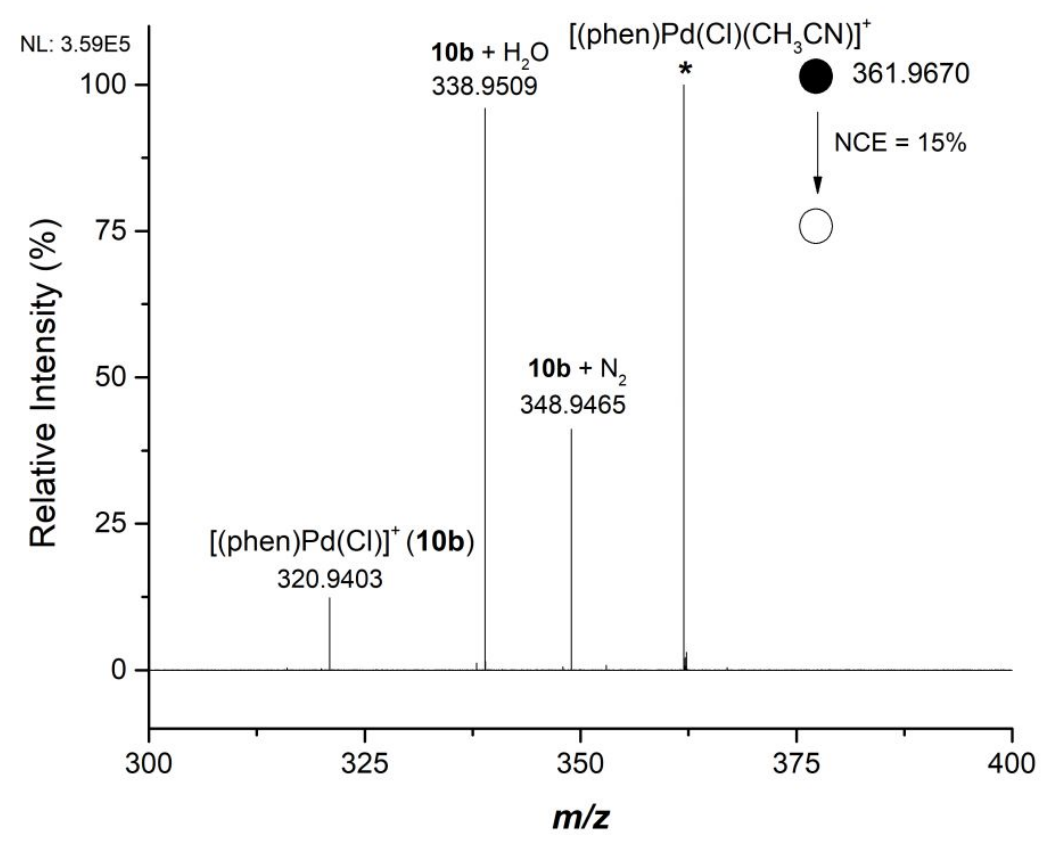

Figure S13. Single isotope $\mathrm{MS}^{2}$ low energy ion-trap CID experiment on $\left[(\mathrm{phen}) \mathrm{Pd}(\mathrm{Cl})\left(\mathrm{CH}_{3} \mathrm{CN}\right)\right]^{+}(\mathrm{m} / \mathrm{z} 361.9670)$ as the mass-selected precursor ion showing the formation of $[(\mathrm{phen}) \mathrm{Pd}(\mathrm{Cl})]^{+}(\mathbf{1 0 b})(\mathrm{m} / \mathrm{z} 320.9403)$, obtained using a $\mathrm{Q}$ value of 0.25 , an activation time of $10 \mathrm{~ms}$ and the normalized collision energy (NCE) $15 \%$. (*) represents the mass-selected precursor ion.

\section{$\underline{\text { References }}$}

S1. Mazurek, U.; Schwarz, H., Carbon-fluorine bond activation-looking at and learning from unsolvated systems. Chem. Commun. 2003, 1321-1326.

S2. Rijs, N. J.; O’Hair, R. A. J., Forming trifluoromethylmetallates: competition between decarboxylation and C-F bond activation of group 11 trifluoroacetate complexes, $\left[\mathrm{CF}_{3} \mathrm{CO}_{2} \mathrm{ML}\right]^{-}$. Dalton Trans. 2012, 41, 3395-3406.

S3. O'Hair, R. A. J.; Rijs, N. J., Gas Phase Studies of the Pesci Decarboxylation Reaction: Synthesis, Structure, and Unimolecular and Bimolecular Reactivity of Organometallic Ions. Acc. Chem. Res. 2015, 48, 329-340.

S4. Cordero, M. M.; Wesdemiotis, C., Characterization of the Neutral Products Formed upon Charge-Remote Fragmentation of Fatty Acid Ions. Anal. Chem. 1994, 66, 861-866. 
S5. Woolley, M. J.; Khairallah, G. N.; Donnelly, P. S.; O’Hair, R. A. J., Nitrogen adduction by three coordinate group 10 organometallic cations: platinum is favoured over nickel and palladium. Rapid Commun. Mass Spectrom. 2011, 25, 2083-2088.

S6. Greis, K.; Yang, Y.; Canty, A. J.; O’Hair, R. A. J., Gas-Phase Synthesis and Reactivity of Ligated Group 10 Ions in the Formal +1 Oxidation State. J. Am. Soc. Mass Spectrom. 2019, 30, 1867-1880. 